\title{
PENINGKATAN KETERAMPILAN BERBICARA ANAK USIA DINI MELALUI PERMAINAN SANDIWARA BONEKA
}

\section{IMPROVING EARLY CHILD SPEAKING SKILLS THROUGH PUPPET PLAYS}

\author{
Mila Faila Shofa, Suparno \\ Universitas Muhammadiyah Surakarta, Universitas Negeri Yogyakarta \\ mila_87shofa@yahoo.co.id, suparno_plb@uny.ac.id
}

\begin{abstract}
Abstrak
Penelitian ini bertujuan untuk: (1) mengimplementasikan kegiatan permainan sandiwara boneka dalam mengembangkan keterampilan berbicara peserta didik di PAUD SAYMARA Kartasura kelompok A, (2) meningkatkan keterampilan berbicara anak usia dini melalui permainan sandiwara boneka di PAUD SAYMARA Kartasura kelompok A. Jenis penelitian ini adalah Penelitian Tindakan Kelas. Subjek dalam penelitian ini adalah anak didik kelompok A di PAUD SAYMARA Kartasura tahun ajaran 2013/2014. Penelitian ini bersifat kolaboratif antara peneliti, guru kelas, dan kepala sekolah. Data dikumpulkan melalui observasi, catatan lapangan, wawancara, dan dokumentasi. Data dianalisis secara deskriptif kualitatif model alur. Hasil penelitian ini menunjukkan bahwa (1) implementasi permainan sandiwara boneka meliputi kegiatan awal, kegiatan inti, dan kegiatan penutup. Kegiatan awal berupa apersepsi dan pengenalan tokoh, pada kegiatan inti guru menunjukkan permainan sandiwara boneka, dan kegiatan akhir peserta didik menceritakan kembali dengan permainan sandiwara boneka. (2) permainan sandiwara boneka dapat meningkatkan keterampilan berbicara anak usia dini. Peningkatan prosentase keterampilan berbicara dari sebelum tindakan sampai dengan siklus II yakni sebelum tindakan 40,13\%, siklus I mencapai 61,08 \%, siklus II mencapai 79,74\%.
\end{abstract}

Kata kunci: keterampilan berbicara, anak usia dini, permainan sandiwara boneka.

\begin{abstract}
The study aims to: (1) implement puppet play activities in developing speaking skills in PAU Improving Early Child Speaking Skills through Puppet Plays (A Classroom Action Research in PAUD Kartasura SAYMARA Group A in the Academic Year of 2013/2014)D SAYMARA Kartasura group A, and (2) improve speaking skills in early child through puppet plays in PAUD SAYMARA Kartasura group A.This research is Classroom Action Research. The subjects in this study are students in PAUD SAYMARA group A Kartasura in the Academic Year of 2013/2014. This research is a collaborative research, between researcher, classroom teachers, and school headmaster. Data validity were checked by triangulation. Data were analyzed by descriptive qualitative flow models. The results indicate that (1) the implementation of puppet play include first activity, core activity, and closing activity. First activity include apperception and character recognition, teacher show the puppet plays in the core activity, and the final activity student retell the puppet plays. (2) puppet plays can improve speaking skills in early child. The percentage of speaking skills in pre cycle is $40.13 \%$, in first cycle $61.08 \%$ and in the second is $79.74 \%$.
\end{abstract}

Keywords: speaking skills, early child, puppet plays. 


\section{PENDAHULUAN}

Pendidikan Anak Usia Dini (PAUD) merupakan pendidikan yang diselenggarakan untuk mengembangkan pribadi, pengetahuan, dan keterampilan yang melandasi pendidikan dasar serta mengembangkan diri secara utuh sesuai dengan asas pendidikan sedini mungkin dan seumur hidup. Undang-Undang RI No. 20 Tahun 2003 Tentang Sistem Pendidikan Nasional Pasal 1 Butir 14 yang menyebutkan bahwa pendidikan anak usia dini adalah suatu upaya pembinaan yang ditujukan kepada anak sejak lahir sampai dengan usia enam tahun yang dilakukan melalui pemberian rangsangan pendidikan untuk membantu pertumbuhan dan perkembangan jasmani dan rohani agar anak memiliki kesiapan dalam memasuki pendidikan lebih lanjut.

Masa usia dini merupakan periode emas (golden age) bagi perkembangan anak untuk memperoleh proses pendidikan. Periode ini adalah tahun-tahun berharga bagi seorang anak untuk mengenali berbagai macam fakta di lingkungannya sebagai stimulan terhadap perkembangan kepribadian, psikomotor, bahasa, kognitif maupun sosialnya. Anak usia dini yang mendapat rangsangan cukup dalam mengembangkan kedua belah otaknya akan memperoleh kesiapan yang menyeluruh untuk belajar dengan sukses/berhasil pada saat memasuki jenjang Sekolah Dasar (SD).

Pendidikan anak usia dini memberi kesempatan untuk mengembangkan kepribadian anak, oleh karena itu lembaga pendidikan anak usia dini perlu menyediakan berbagai kegiatan yang dapat mengembangkan berbagai aspek perkembangan yang meliputi kognitif, bahasa, sosial, emosi, fisik dan motorik. Sesuai dengan keunikan dan pertumbuhan anak usia dini, maka penyelenggaraan PAUD disesuaikan dengan tahap-tahap perkembangan yang dilalui oleh anak usia dini. Program pendidikan anak usia dini harus disusun secara sistematis dan bermakna bahwa ada bahan-bahan pengembangan yang sudah berurut (sequensial) dan diklasifikasikan sesuai dengan program ranah perkembangan potensi anak.
Manusia dalam kehidupannya tidak terlepas dari bahasa. "Bahasa digunakan sebagai alat komunikasi. Dengan bahasa, mereka akan mudah dalam bergaul dan mudah menyesuaikan diri dengan lingkungannya. Brooks (2012, p.9) mengatakan bahwa "natural pedagogy the use of ostensive signals to indicate that cultural knowladge is being taught within a commuicative interaction". Anak-anak akan memahami pengetahuan tentang lingkungan, budaya maupun alam melalui interaksi komunikasi. Salah satu bentuk komunikasi yang dilakukan anak adalah dengan berbicara. Keterampilan berbicara merupakan salah satu keterampilan berbahasa yang harus dikembangkan sejak dini. Berbicara adalah suatu proses berkomunikasi dengan penyampaian maksud (ide, pikiran, gagasan, atau isi hati kepada seseorang dengan menggunakan bahasa lisan agar dapat dipahami oleh orang lain. Melalui berbicara anak dapat mengungkapkan pendapat, pikiran dan perasaannya.

Vygotsky (Santrock 2007, p.265) mengatakan bahwa "anak menggunakan pembicaraan bukan saja untuk berkomunikasi sosial, tetapi juga untuk membantu mereka menyelesaikan tugas". Anak pada usia dini menggunakan bahasa untuk merencanakan, membimbing, dan memonitor perilaku mereka. Bahasa dan pikiran pada awalnya berkembang terpisah kemudian menyatu. Sebagai contoh anak harus menggunakan bahasa untuk berkomunikasi kepada orang lain sebelum mereka memfokuskan ke dalam pikiran-pikiran mereka sendiri. Disinilah arti pentingnya bahasa dalam mengembangkan kognitif dan pikiran anak.

Berdasarkan pengamatan peneliti, permasalahan yang dihadapi oleh pendidik PAUD adalah kurangnya pemahaman tentang metode yang tepat untuk menstimulasi keterampilan bicara peserta didik yang mengakibatkan rendahnya kemampuan bahasanya. Peserta didik kurang bisa mengungkapkan pendapat dan pikirannya dengan bahasa verbalnya. Guru kurang memanfaatkan alat peraga secara maksimal, kurang bisa mengelola kelas, kurang bisa memotivasi peserta didik dalam melakukan kegiatan, serta pada saat proses pembelajaran masih berpusat pada guru sehingga 
peserta didik menjadi bosan dengan metode yang digunakan.

Berdasarkan pengamatan lapangan di PAUD SAYMARA Kartasura kelompok A, bahasa yang digunakan dalam pembelajaran adalah bahasa Indonesia, hal ini sama dengan bahasa yang digunakan peserta didik di rumah yakni bahasa Indonesia dan bahasa Jawa. Peneliti melihat keterampilan berbicara peserta didik masih kurang yakni sebagian besar $(73 \%)$ peserta didik belum mencapai tingkat pencapaian perkembangan berbicara. Sebagian besar peserta didik masih kurang bisa mengungkapkan pendapat dan pemikirannya, kosa kata yang dimiliki peserta didik juga cederung masih kurang. Peserta didik kurang bisa mengulang kembali kalimat sederhana yang diucapkan oleh guru maupun orang lain. Peserta didik cenderung pendiam, kurang komunikatif dengan guru dan teman. Peserta didik kurang mampu menjawab pertanyaan guru, selain itu peserta didik juga belum mampu dalam menceritakan kembali isi cerita dengan lancar dan tepat.

Berdasarkan temuan tersebut dan mengingat perkembangan kemampuan berbicara di Taman Kanak-kanak sangatlah penting, maka upaya guru dalam meningkatkan keterampilan berbicara peserta didik adalah dengan menciptakan suasana belajar yang kondusif dan komunikatif agar tercipta suasana yang menyenangkan dan mampu mencapai tujuan dalam proses pembelajaran tersebut. Dalam mengembangkan keterampilan berbicara ini guru sebaiknya menggunakan metode bermain sehingga secara tidak langsung dan tidak sadar peserta didik sudah mengembangkan penguasaan bahasa dengan sendirinya.

Permainan sandiwara boneka adalah merupakan metode yang dapat diterapkan ketika guru akan bercerita dalam proses belajar mengajar di Taman Kanak-kanak. Menurut Musfiroh (2005, p.147) "boneka menjadi alat peraga yang dianggap mendekati naturalitas bercerita. Tokoh-tokoh yang diwujudkan melalui boneka berbicara dengan gerakan-gerakan yang mendukung cerita dan mudah diikuti anak". Bercerita merupakan metode yang efektif dalam mengembangkan bahasa anak. Hal ini sesuai dengan pendapat Essa (2003, p.341) yang menyatakan bahwa

Stories, in their various forms, are the most popular vehicle for such activities. Stories can be told or ready by teachers, children or both together; they can be enacted by children or with flannelboard pieces, puppets, or play dough; or they can come from the rich store of children's literature or be made up out of the febric of the children's experiences. We will briefly look at some of the ways in which stories can be used and presented.

Essa menyatakan bahwa segala bentuk cerita merupakan kegiatan yang paling menarik. Cerita dapat disampaikan oleh guru, anak maupun keduanya. Cerita dapat disampaikan dengan papan flanel, boneka/ wayang, play dough, atau dapat diambil dari buku-buku cerita. Anak-anak akan tertarik dengan berbagai cara dalam penyampaian cerita.

Metode permainan sandiwara boneka dapat digunakan karena metode ini berbagai kelebihan, diantaranya peserta didik akan lebih tertarik mengikuti kegiatan karena tokoh cerita berupa boneka yang beraneka ragam sehingga peserta didik lebih antusias mengikuti kegiatan bercerita. Boneka merupakan sesuatu yang sangat diminati anak, mengingat bentuknya yang lucu sehingga memperkaya imajinasinya. Panggung boneka yang didesain untuk bercerita juga meningkatkan kemampuan peserta didik untuk membangun pengetahuannya tentang isi cerita secara keseluruhan meliputi alur, tokoh, dan setting cerita. Guru juga lebih semangat untuk bercerita karena bebas berekspresi melalui tokoh boneka yang dibawanya.

Berdasarkan latar belakang tersebut maka peneliti mengambil judul penelitian "Peningkatan Keterampilan Berbicara Anak Usia Dini Melalui Permainan Sandiwara Boneka (Sebuah Penelitian Tindakan Kelas di PAUD SAYMARA Kartasura Kelompok A Tahun Ajaran 2013/2014)".

Penelitian ini bertujuan untuk mengimplementasikan kegiatan permainan sandiwara boneka dalam mengembangkan keterampilan berbicara peserta didik di PAUD 
SAYMARA Kartasura kelompok A, serta meningkatkan keterampilan berbicara anak usia dini melalui permainan sandiwara boneka di PAUD SAYMARA Kartasura kelompok A.

Berdasarkan tujuan penelitian yang hendak dicapai, maka penelitian ini diharapkan mempunyai manfaat dalam pendidikan baik secara langsung maupun tidak langsung. Adapun manfaat secara teoritis hasil penelitian ini diharapkan dapat memberikan sumbangan pemikiran bagi pengembangan kurikulum pendidikan anak usia dini yang terus berkembang sesuai dengan tuntutan masyarakat dan kemajuan ilmu pengetahuan dan teknologi dimasa yang akan datang, memberikan sumbangan ilmiah dalam ilmu Pendidikan Anak Usia Dini, yaitu membuka wawasan memaksimalkan permainan sandiwara boneka untuk meningkatkan keterampilan berbicara pada anak usia dini, dan sebagai pijakan dan referensi pada penelitian-penelitian selanjutnya yang berhubungan dengan peningkatan keterampilan berbicara pada anak usia dini serta menjadi bahan kajian lebih lanjut.

Secara praktis penelitian ini dapat bermanfaat bagi penulis yakni menambah wawasan dan pengalaman langsung tentang cara meningkatkan keterampilan berbicara pada anak usia dini, khususnya melalui permainan sandiwara boneka. Bagi pendidik dan calon pendidik, dapat menambah pengetahuan dan sumbangan pemikiran tentang cara meningkatkan keterampilan berbicara anak usia dini, khususnya melalui permainan sandiwara boneka. Bagi anak didik sebagai subjek penelitian, diharapkan dapat memperoleh pengalaman langsung mengenai pembelajaran secara aktif, kreatif dan menyenangkan melalui permainan sandiwara boneka. Anak didik akan lebih berkembang keterampilan berbicaranya yang sesuai dengan perkembangan berfikirnya. Bagi sekolah tempat anak belajar, sebagai bahan pertimbangan dalam menyusun program pembelajaran serta menentukan metode dan media pembelajaran yang tepat untuk meningkatkan keterampilan berbicara pada anak usia dini.
Kajian penelitian yang relevan dengan penelitian ini, antara lain penelitian oleh Rachmawati Nur Hidayah (UMS: 2011) tentang peningkatan kecerdasana verbal linguistik anak melalui kegiatan bermain punggung berantai di RA BAKTI IX Tohudan, Colomadu menunjukkan bahwa prosentase keberhasilan peningkatan kecerdasan verbal linguistik dengan permainan huruf punggung berantai pada penelitian ini, yakni sebelum tindakan $23,75 \%$, siklus I mencapai $32,5 \%$, siklus II mencapai $61,25 \%$, dan siklus III mencapai $68,75 \%$. Penelitian oleh Janet Scull, Louise Paatsch, dan Bridie Raban (University of Melbourne, Deakin University, and University of Melbourne: 2013) yang berjudul 'Young Learners: Teachers' Questions and Prompts as Opportunities for Children's Language Development" menyatakan bahwa hal sangat penting untuk belajar bahasa adalah membaca buku dan melibatkan anak pada diskusi seputar teks yang dibaca. Dalam pembelajaran ini, perkembangan bahasa lisan anak prasekolah tergantung pada banyaknya peluang yang disediakan tentang keterlibatan dalam penggunaan bahasa yang disediakan oleh guru. Untuk mengeksplorasi interaksi dan keterampilan bicara anak dalam membaca buku, pertanyaan guru dalam menaggapi anak harus dilakukan.

Penelitian oleh Bardani (UMS: 2010) tentang peningkatan kemampuan bahasa lisan melalui kegiatan membacakan cerita (story reading) pada Anak Didik Kelompok B TK Aisyiyah II Ngadirejo Kartasura Tahun Pelajaran 2009/2010 menyatakan bahwa hasil yang diperoleh dari penelitian ini antara lain: (1) penerapan metode membacakan cerita (story reading) dapat meningkatkan kemampuan bahasa lisan anak, Hal ini ditandai dengan prosentase pada indikator menceritakan kembali isi cerita pada pra tindakan diperoleh $28 \%$, siklus I $44 \%$, siklus II $72 \%$, dan siklus III $80 \%$, (2) pada indikator menjawab pertanyaan pada pra tindakan diperoleh prosentase $32 \%$, siklus $44 \%$, siklus II $72 \%$, dan siklus III 88\%.(3) sedangkan pada indikator membaca gambar pada pra tindakan diperoleh prosentase $36 \%$, siklus I $48 \%$, siklus II $80 \%$, sedangkan siklus III $84 \%$. 
Penelitian oleh Jeong Hwa Lee, Jeong Eon Park (Pukyong Nasional University of Korea: 2009) yang berjudul "Differences of children's verbal interaction in peer collaboration according to age, gender, and pairing conditions". Tujuan penelitian ini adalah untuk menyelidiki interaksi verbal anakanak dalam pemecahan masalah secara bersama sesuai dengan usia anak, jenis kelamin dan kondisi orang tua. Anak yang ditempatkan dalam tingkat yang sama dan dalam tingkat yang berbeda. Interaksi verbal setiap tingkatan yang sama, bekerja dengan tugas blok kolaboratif, direkam dan kemudian ditranskrip untuk analisis. Hasilnya, perbedaan antara kelompok yang sama dan yang tidak sama, anak laki-laki dan perempuan, dan anak dengan usia 4 dan 5 tahun dengan nilai total interaksi verbal yang diamati, berpengaruh signifikan dan pengaruh interaksi gender untuk interaksi berorientasi pada tugas dan interaksi dukungan yang efektif diamati.

Penelitian-penelitian di atas hampir sama dengan penelitian yang akan dilakukan, yaitu penelitian tentang kemampuan bahasa anak usia dini, hanya saja penelitian ini memfokuskan pada implementasi pengembangan keterampilan berbicara melalui kegiatan bercerita dengan sandiwara boneka pada anak usia Taman Kanak-kanak kelompok A (usia 4-5 tahun).

Penelitian oleh Rachmawati Nur Hiayah meneliti tentang peningkatan kecerdasan verbal linguistik anak melalui kegiatan bermain punggung berantai, sedangkan penelitian ini memfokuskan pada kecerdasan bahasa, khususnya bahasa ekspresif yakni keterampilan berbicara, dan metode yang digunakanpun menggunakan metode permainan sandiwara boneka. Penelitian oleh Janet Scull, et.al menyebutkan bahwa perkembangan bahasa lisan anak prasekolah tergantung pada banyaknya peluang yang disediakan oleh guru dalam penggunaan bahasa. Berdasarkan penelitian tersebut, penelitian ini juga akan memberikan peluang yang banyak kepada anak untuk berbicara melalui interaksi guru dan anak.

Penelitian oleh Bardani meneliti tentang peningkatan kemampuan bahasa lisan melalui kegiatan membacakan cerita (story reading). Sedangkan pada penelitian ini memfokuskan pada peningkatan keterampilan berbicara melalui permainan sandiwara boneka. Penelitian oleh Jeong Hwa Lee, et.al menemukan bahwa usia, gender, dan kondisi kelompok berpengaruh signifikan terhadap interaksi verbal. Berdasarkan penelitian tersebut, penelitian ini juga akan melihat usia sebagai bahan analisis keterampilan berbicara anak.

\section{METODE}

Metode adalah suatu cara yang digunakan untuk mencapai tujuan. Dalam Nazir (1995, p.15) penelitian adalah penyelidikan yang hati-hati dan kritis dalam mencari fakta dan prinsip. Jadi, dapat disimpulkan metode penelitian adalah cara yang disusun secara sistematis dengan mengikuti konsep-konsep ilmiah yang digunakan dalam rangka pencarian data dan fakta demi tercapainya tujuan.

\section{Jenis Penelitian}

Penelitian ini termasuk penelitian tindakan kelas (PTK) atau dalam bahasa Inggris sering disebut Classroom Action Research $(C A R)$. Penelitian Tindakan Kelas (PTK) adalah sebuah proses pengkajian masalah pembelajaran di dalam kelas melalui refleksi diri dalam upaya untuk memecahkan masalah tersebut dengan cara melakukan berbagai tindakan yang terencana dalam situasi nyata serta menganalisis setiap pengaruh dari perlakuan tersebut (Sanjaya, 2009, p.26). Penelitian yang dimaksudkan untuk memberikan informasi bagaimana tindakan yang tepat untuk meningkatkan keterampilan berbicara anak usia dini. Penelitian Tindakan Kelas merupakan kegiatan pemecahan masalah yang dimulai dari: (a) perencanaan (planning), (b) pelaksanaan (action), (c) pengumpulan data (observing), (d) menganalisis data/informasi untuk memutuskan sejauh mana kelebihan atau kelemahan tindakan tersebut (reflecting).

PTK bercirikan perbaikan terus menerus sehingga kepuasan peneliti menjadi tolak ukur berhasilnya (berhentinya) siklussiklus tersebut. Hal ini dirunut dari teori Mc Taggart (1993, p.31) yang menjelaskan, 
... for the three kinds of action research proposed above there were some basic features. In these conceptualizations, action research was constituted in the series of cycles of deliberate planning, action, observation, and reflection, conducted by practitioners in their own work.

Konsep tersebut dilakukan untuk meningkatkan kemantapan rasional dalam melaksanakan tugas sehari-hari, memperdalam pemahaman terhadap tindakantindakan yang dilakukan, dan memperbaiki kondisi dimana praktik pembelajaran dilakukan. Prinsip penelitian tindakan dilakukan dengan kegiatan nyata yang dilaksanakan dalam situasi rutin dan belajar efektif, artinya proses tindakan penelitian tidak dilaksanakan pada waktu tertentu misalnya saat libur semester, hari minggu dan seterusnya, tapi bersamaan dengan kegiatan belajar biasa. Proses belajar berjalan normal sehingga peserta didik tidak mengetahui gurunya sedang melakukan penelitian.

Penelitian ini dilakukan secara kolaboratif antara kepala sekolah, guru, dan peneliti. Hal ini dilakukan untuk menyamakan pemahaman, kesepakatan tentang permasalahan, pengambilan keputusan yang akhirnya melahirkan kesamaan tindakan (action). Penelitian ini bersifat praktis, situasional dan kontekstual berdasarkan permasalahan yang muncul dalam kegiatan pembelajaran sehari-hari di Taman Kanakkanak. Kepala sekolah, guru dan peneliti senantiasa berupaya memperoleh hasil yang optimal melalui cara dan prosedur yang efektif sehingga dimungkinkan adanya tindakan yang berulang-ulang dengan revisi untuk meningkatkan penguasaan bahasa lisan anak.

\section{Waktu dan Tempat}

Penelitian ini dilaksanakan pada bulan November sampai Maret tahun 2014, bertempat di PAUD SAYMARA Kartasura kelompok A.

\section{Subjek}

Subjek penelitian ini adalah peserta didik di PAUD SAYMARA Kartasura dengan pertimbangan bahwa peserta didik pada sekolah ini memiliki kemampuan yang heterogen dalam keterampilan berbicara. Dalam penelitian ini dipilih satu kelas yaitu siswa kelompok A karena anak-anak pada kelompok ini berusia 4-5 tahun yang sedang berkembang kemampuan berbicaranya, sehingga dengan penelitian ini diharapkan dapat bermanfaat bagi perkembangan peserta didik selanjutnya.

\section{Rencana Tindakan}

Pelaksanaan tindakan dilakukan berdasarkan alur tindakan yang telah disebutkan tersebut, meliputi perencanaan (planning), pelaksanaan (action), pengumpulan data (observing), dan menganalisis data/informasi untuk memutuskan sejauh mana kelebihan atau kelemahan tindakan tersebut (reflecting).

Perencanaan tindakan (planning). Langkah-langkah persiapan yang dilakukan untuk mengadakan tindakan terdiri dari: (a) mempersiapkan media dan sumber pembelajaran. Media yang digunakan dalam penelitian ini adalah boneka. Adapun boneka yang digunakan adalah boneka tangan, boneka jari, dan boneka wayang. Selain itu kegiatan sandiwara boneka ini akan menggunakan panggung boneka sebagai media pendukungnya. (b) mempersiapkan waktu pembelajaran. Waktu keseluruhan yang dibutuhkan dalam kegiatan bermain sandiwara boneka direncanakan selama \pm 30 menit. (c). membuat rencana pembelajaran. Rencana pembelajaran yang digunakan pada penelitian ini berupa Rencana Kegiatan Harian (RKH). Tema pembelajaran adalah Rekreasi, sedangkan materi yang disampaikan adalah cerita tentang pergi rekreasi dan tokoh binatang, mengingat kebun binatang merupakan subtema pada tema rekreasi di sekolah tersebut.

Pelaksanaan Tindakan (Acting). Tindakan dilaksanakan berdasarkan perencanaan. rencana tindakan ini bersifat tentatif dan sementara, fleksibel dan siap diubah sesuai dengan kondisi yang ada sebagai usaha kearah perbaikan. Pelaksanaan tindakan dilaksanakan dalam waktu antaraı sampai 1,5 bulan. Penelitian tindakan kelas ini besifat kolaboratif antara peneliti, guru, dan kepala sekolah. Guru sebagai pelaksana 
tindakan dan dibantu oleh peneliti, sedangkan kepala sekolah mengamati dan memberikan evaluasi. Adapun proses tindakannya meliputi (a) guru memberikan arahan kepada peserta didik di kelas bahwa sekarang waktunya bermain sandiwara boneka. Membuat peserta didik senang dan penasaran. Hal ini dilakukan dengan bernyanyi, memperlihatkan boneka yang menarik agar peserta didik bersemangat untuk mengikuti kegiatan. (b) setelah peserta didik merasa riang gembira dan siap mengikuti kegiatan, kegiatan awal yang dilakukan dengan cara bernyanyi dan apersepsi tentang materi yang akan disampaikan. Adapun pada tindakan pertama ini materi akan disampaikan bertema rekreasi, dengan sub tema binatang. Guru melakukan tanya jawab tentang macam-macam binatang. (c) guru menunjukkan boneka tangan dan panggung sandiwara, memperkenalkan tokoh-tokoh cerita, kemudian mulai bercerita dengan judul "Sapi yang Gemar Makan". Guru membuat peserta didik menikmati cerita, sesekali guru mengadakan tanya jawab dengan peserta didik melalui tokoh yang diperankan. Guru menyampaikan cerita sampai akhir cerita. (d) di akhir kegiatan ini, guru melakukan review cerita yang telah didengar peserta didik. Guru melakukan tanya jawab dan mengobservasi kemampuan peserta didik dengan dibantu oleh peneliti. Siapa saja anak yang bisa menjawab, berapa jumlah pertanyaan yang dapat dijawab anak dicatat oleh peneliti dan dibantu oleh guru kelas.

Pengamatan/observasi dilakukan dengan menggunakan lembar pengamatan menurut aspek-aspek identifikasi, waktu pelaksanaan, pendekatan, metode dan tindakan yang dilakukan peneliti, tingkah laku peserta didik serta kelemahan dan kelebihan yang ditemukan.

Refleksi merupakan tahapan yang dimaksudkan untuk mengkaji secara menyeluruh tindakan yang telah dilakukan, berdasarkan data hasil pengamatan yang telah terkumpul, kemudian dilakukan analisis dan evaluasi guna merancang tindakan berikutnya. Refleksi mencakup analisis, sintesis, dan penilaian terhadap hasil pengamatan atas tindakan yang dilakukan. Jika terdapat masalah dari proses refleksi maka dilakukan proses pengkajian ulang melalui siklus berikutnya. Hopkins (Arikunto, 2007, p.8o). Kegiatan refleksi ini dilakukan setiap akhir kegiatan bercerita dengan sandiwara boneka.

\section{Teknik dan Instrumen Pengumpulan Data}

Data dalam penelitian bersumber dari interaksi guru dan siswa dalam pembelajaran dan berupa data tindakan belajar atau perilaku belajar yang dihasilkan dari tindakan yang mengajar. Data yang diambil disini adalah data tentang keterampilan berbicara pada anak usia dini. Pengambilan data pada penelitian ini dilakukan dengan observasi, catatan lapangan, wawancara, dan dokumentasi.

Pengumpulan data melalui observasi dilakukan oleh peneliti dan guru kelas pada subjek penelitian untuk mendapatkan gambaran secara langsung kegiatan belajar peserta didik dikelas. Observasi yang dilakukan meliputi observasi tentang proses pembelajaran bahasa serta keterampilan berbicara peserta didik setelah kegiatan bercerita dengan sandiwara boneka. Dalam melakukan observasi ini, peneliti berpedoman pada lembar observasi. Observasi dilakukan meliputi observasi tentang keterampilan guru dalam mengajar serta observasi tentang keterampilan berbicara peserta didik dalam kegiatan permainan sandiwara boneka. Skala pengukuran yang digunakan dalam instrumen ini adalah numerical rating scale. Widiyoko (2012, p.120) mengatakan bahwa komponen numerical rating scale adalah pernyataan tentang kualitas tertentu yang menunjukkan skor sesuatu yang akan diukur, yang diikuti oleh angka yang menunjukkan skor sesuatu yang diukur.

Wawancara dan diskusi dengan guru dilaksanakan setelah melakukan pengamatan pertama terhadap kegiatan pembelajaran, yang dimaksudkan untuk memperoleh informasi tentang berbagai hal yang berkaitan dengan pelaksanaan pembelajaran bahasa pada anak usia dini. Dari wawancara, pengamatan dan kajian dokumen yang telah dilakukan diidentifikasi permasalahan-permasalahan yang ada berkenaan dengan 
pembelajaran bahasa lisan serta faktorfaktor penyebabnya.

Catatan lapangan digunakan untuk mencatat temuan selama pembelajaran yang diperoleh peneliti yang tidak teramati dalam lembar observasi bentuk temuan ini berupa aktivitas peserta didik dan permasalahan yang dihadapi selama pembelajaran melalui metode bercerita dengan sandiwara boneka. Dokumentasi dilakukan untuk memperoleh atau mengetahui sesuatu dengan buku-buku, arsip yang berhubungan dengan yang diteliti. Dokumentasi digunakan untuk memperoleh data sekolah dan nama siswa kelompok A PAUD SAYMARA Kartasura. Dokumentasi juga berupa foto rekaman proses tindakan penelitian, yaitu rekaman proses pembelajaran melalui metode bercerita dengan sandiwara boneka.

\section{Teknik Analisis Data}

Penelitian ini menggunakan triangulasi penyelidikan dengan jalan memanfaatkan peneliti atau penguatan untuk pengecekan kembali derajat kepercayaan data. Pada penelitian tindakan kelas ini, data dianalisis sejak tindakan pembelajaran dilakukan dan dikembangkan selama proses refleksi sampai proses penyusunan laporan. Data dianalisis secara diskriptif kualitatif dengan analisis interaktif yang terdiri dari reduksi data, penyajian data, dan penarikan simpulan dilakukan dalam bentuk interaktif dengan pengumpulan data sebagai suatu proses siklus.

\section{HASIL DAN PEMBAHASAN}

Penelitian ini dilakukan selama 2 siklus. Masing-masing siklus terdiri dari 3 pertemuan. Berdasarkan observasi peneliti sebelum tindakan diketahui bahwa stimulasi keterampilan berbicara anak dilakukan dengan metode tanya jawab atau kuis menjelang masuk kelas dan menjelang pulang, bernyanyi, sajak, bercerita, dan lain sebagainya. Pengembangan keterampilan berbicara anak belum menggunakan media boneka/ sandiwara boneka menggunakan boneka jari, boneka tangan, panggung boneka maupun boneka wayang. Kegiatan untuk pengembangan keterampilan berbicara sering dilakukan dengan bercakap-cakap.
Selain itu kegiatan pembelajaran dengan model pembelajaran sentra sehingga sebagian besar waktu anak digunakan untuk melakukan kegiatan sentra.

Pada umumnya sebagian peserta didik mempunyai keterampilan berbicara yang cukup. 13 peserta didik baru mulai berkembang keterampilan berbicaranya yakni mulai bisa mengucapkan kata/kalimat tetapi dengan irama/ritme yang kurang jelas, 5 peserta didik mulai bisa mengungkapkan pendapat dan pemikirannya. Selain itu berdasarkan observasi dan wawancara kepada anak didik, peneliti melihat adanya kecenderungan anak-anak yang pendiam, kurang bisa berpartisipasi secara lisan dalam kegiatan pembelajaran, dan kurang bisa mengungkapkan pikiran dan perasaan dengan baik. Walaupun ada juga beberapa anak yang bisa dikatakan kritis dalam berbicara, banyak bertanya, dan dapat mengungkapkan pikiran dengan baik.

Untuk mengetahui keterampilan berbicara anak didik sebelum tindakan, penulis melakukan observasi dalam pembelajaran. Pada kegiatan ini peneliti mengobservasi pada kegiatan awal pembelajaran anak-anak kelompok A PAUD SAYMARA. Dalam kegiatan awal ini guru menstimulasi keterampilan berbicara anak melalui kegiatan bercakap-cakap. Dari observasi tersebut, anakanak terlihat mengikuti kegiatan dengan baik dan beberapa anak sudah aktif dan berpartisipasi dalam pembelajaran. Guru memulai dengan mengajak anak-anak untuk bernyanyi dengan judul "binatang", ada beberapa anak yang hafal tetapi ada juga yang tidak hafal dan berusaha untuk menirukan. Kemudian guru bercakap-cakap dan bercerita tentang binatang, seperti sapi, burung gagak, dan kucing. Setelah menyebutkan nama-nama binatang, guru mulai bercakap-cakap dengan anak. Selama bercerita guru melakukan percakapan kepada anak untuk mengetahui keterampilan berbicaranya. Beberapa anak bisa mengungkapkan pendapat dan pikirannya seperti "aku pernah melihat sapi di sawah". Ada juga yang mengungkapkan "kucing kok di sawah sama sapi", dan lain sebagainya. Setelah selesai bercakap-cakap, guru melakukan tanya jawab tentang cerita yang disampaikan 
serta meminta anak untuk menceritakan kembali isi cerita yang disampaikan oleh peneliti. Beberapa anak sudah respon ketika ditanya tentang cerita yang disampaikan, ada anak yang mengungkapkan "bu.. kakekku pernah di sawah nyangkul ketemu sama tuan Crap (maksudnya kepiting)" karena sering nonton Spongsbob. Ada juga satu anak yang mau menceritakan kembali cerita yang disampaikan guru, akan tetapi masih terbata-bata dan dibantu oleh guru. Dari hasil observasi tersebut secara keseluruhan didapatkan daya serap kelas/prosentase penguasaan kelas baru mencapai 40,13\%.

Berdasarkan pengamatan pada tindakan siklus I Berdasarkan pengamatan yang dilakukan peneliti dan guru, diperoleh hasil sebagai berikut: (1) sebagian besar anak semangat dan antusias dalam mengikuti kegiatan permainan sandiwara boneka, (2) beberapa anak masih ada yang melihat luar dan tidak memperhatikan guru yang sedang bercerita dengan panggung boneka, (3) ada satu anak merengek, ayo bermain, buguru kok masuk TV terus (4) setelah pertemuan ke 3 waktu yang dibutuhkan terasa kurang, 30 menit waktu pembelajaran tidak cukup, (5) Langga dan Elang pasa pertemuan pertama dan kedua biasanya antusias dan duduk di depan tetapi pada pertemuan ke 3 duduk di belakang dan kurang memperhatikan, (6) anak yang berkebutuhan khusus, dapat duduk tenang selama kegatan sandiwara boneka, dan bisa bicara "mekanik", (7). hasil observasi perkembangan keterampilan berbicara anak sudah cukup menunjukkan peningkatan yaitu dari sebelum tindakan 40,13\%, pada siklus ke I ini mancapai 61,08\%, (7) hasil observasi perkembangan keterampilan berbicara anak juga menunjukkan bahwa ada 3 anak yang mendapat poin tertinggi yaitu berkembang sesuai harapan pada setiap item dalam lembar observasi. (8) ada beberapa item instrumen keterampilan berbicara yang sulit di kuasai oleh anak yakni mengucapkan kalimat pertanyaan dengan irama yang jelas dan mengucapkan kalimat permintaan dengan irama yang jelas, (9) kemampuan guru mengajar dalam permainan sandiwara boneka secara umum sudah cukup baik, akan tetapi keterampilan menyampaikan cerita masih kurang menarik, seperti dalam memegang boneka belum dapat dilihat oleh semua anak, keterampilan menggunakan suara yang bervariasi dalam bercerita juga masih kurang. (10). Peningkatan keterampilan berbicara anak, jika dilihat dari tiap indikator sudah menunjukkan peningkatan, mengucapkan bunyi artikulasi, irama/ritme dari 40,5\% menjadi 59,7\%. Menyampaikan pikiran/gagasan dan perasaan secara lisan dari 40,8\% menjadi $61,75 \%$, Menceritakan kembali cerita/dongeng yang pernah didengar dari $39,1 \%$ menjadi $61,25 \%$.

Berdasarkan hasil pengamatan pada siklus 2, diperoleh hasil sebagai berikut: (1) sebagian besar anak semangat dan antusias dalam mengikuti kegiatan permainan sandiwara boneka, (2) beberapa anak masih ada yang melihat luar dan tidak memperhatikan guru yang sedang bercerita dengan panggung boneka, (3) ada satu anak merengek, ayo bermain, buguru kok masuk TV terus (4) setelah pertemuan ke 3 waktu yang dibutuhkan terasa kurang, 30 menit waktu pembelajaran tidak cukup, (5) Langga dan Elang pasa pertemuan pertama dan kedua biasanya antusias dan duduk di depan tetapi pada pertemuan ke 3 duduk dibelakang dan kurang memperhatikan, (6) anak yang berkebutuhan khusus, dapat duduk tenang selama kegatan sandiwara boneka, dan bisa bicara "mekanik", (7). hasil observasi perkembangan keterampilan berbicara anak sudah cukup menunjukkan peningkatan yaitu dari sebelum tindakan 40,13\%, pada siklus ke I ini mancapai 61,08\%, (7) hasil observasi perkembangan keterampilan berbicara anak juga menunjukkan bahwa ada 3 anak yang mendapat poin tertinggi yaitu berkembang sesuai harapan pada setiap item dalam lembar observasi. (8) ada beberapa item instrumen keterampilan berbicara yang sulit di kuasai oleh anak yakni mengucapkan kalimat pertanyaan dengan irama yang jelas dan mengucapkan kalimat permintaan dengan irama yang jelas, (9) kemampuan guru mengajar dalam permainan sandiwara boneka secara umum sudah cukup baik, akan tetapi keterampilan menyampaikan cerita masih kurang menarik, seperti dalam memegang boneka belum dapat dilihat oleh semua anak, keterampilan 
menggunakan suara yang bervariasi dalam bercerita juga masih kurang. (10). Peningkatan keterampilan berbicara anak, jika dilihat dari tiap indikator sudah menunjukkan peningkatan, mengucapkan bunyi artikulasi, irama/ritme dari 40,5\% menjadi 59,7\%. Menyampaikan pikiran/gagasan dan perasaan secara lisan dari $40,8 \%$ menjadi 61,75\%, Menceritakan kembali cerita/ dongeng yang pernah didengar dari 39,1\% menjadi $61,25 \%$.

Berdasarkan uraian tindakan dari siklus I dan II tersebut, dapat diperoleh hasil penelitian ini adalah melalui permainan sandiwara boneka keterampilan berbicara peserta didik berhasil meningkat dari sebelum tindakan 40,13\% menjadi $61,08 \%$ pada siklus I, dan meningkat lagi menjadi 79,74\% pada siklus II. Keterampilan berbicara anak berhasil meningkat karena adanya proses perbaikan kualitas pembelajaran, khususnya pembelajaran bahasa. Interaksi antara guru dan peserta didik juga ditingkatkan. Peningkatan keterampilan berbicara ini sudah sesuai dengan indikator keberhasilan penelitian ini yakni $75 \%$. Peningkatan keterampilan berbicara anak dari sebelum tindakan sampai siklus ke 2 dapat dilihat pada grafik berikut:

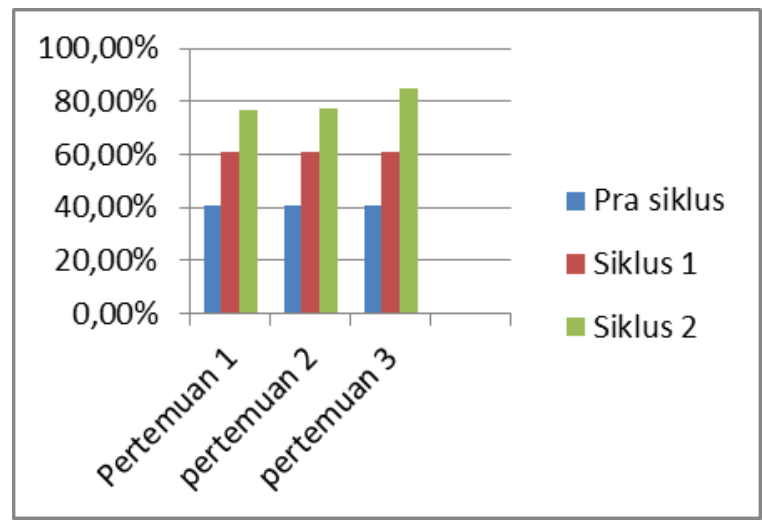

Gambar 1. Grafik Keterampilan Berbicara Anak dari Sebelum Tindakan Sampai Siklus 2

Grafik tersebut merupakan peningkatan keterampian berbicara tiap pertemuan pada siklus II. Adapun peningkatan tiap indikator keterampilan berbicara dapat dilihat pada grafik berikut:

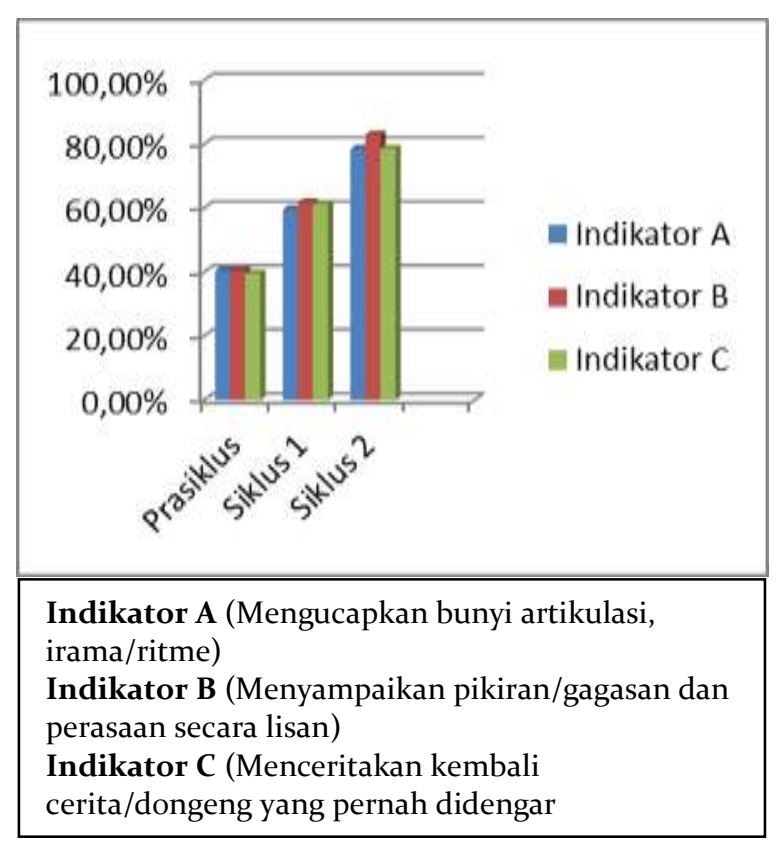

Gambar 2 Keterampilan Berbicara Peserta Didik Tiap Indikator Tiap Siklus

Berdasarkan hasil penelitian tersebut, pembahasan hasil penelitian dapat dijabarkan sebagai berikut: Implementasi Permainan sandiwara boneka dalam proses pembelajaran menunjukkan bahwa keterampilan berbicara anak berhasil meningkat dari sebelum tindakan sampai dengan siklus ke II. Sebelum tindakan 40,13\%, siklus I mencapai $61,08 \%$, dan siklus II mencapai $79,74 \%$. Berdasarkan analisis yang dilakukan oleh peneliti hal ini disebabkan karena implementasi metode dan media digunakan untuk menstimulasi keterampilan berbicara anak. Implementasi Permainan sandiwara boneka Implementasi permainan sandiwara boneka meliputi kegiatan awal, kegiatan inti, dan kegiatan penutup. Kegiatan awal berupa apersepsi dan pengenalan tokoh, pada kegiatan inti guru menunjukkan permainan sandiwara boneka, dan kegiatan akhir peserta didik menceritakan kembali dengan permainan sandiwara boneka. Melalui implementasi permainan sandiwara boneka, kemampuan bahasa anak khususnya bahasa ekspresif yakni berbicara lebih mudah untuk terstimulasi. Melalui permainan sandiwara boneka anak akan lebih tertarik mengikuti kegiatan karena tokoh cerita berupa boneka yang beraneka ragam sehingga anak lebih antusias mengikuti kegiatan bercerita. Boneka merupakan sesuatu 
yang sangat diminati anak, mengingat bentuknya yang lucu sehingga memperkaya imajinasi anak. Panggung boneka yang didesain untuk bercerita juga meningkatkan kemampuan anak untuk membangun pengetahuannya tentang isi cerita secara keseluruhan meliputi alur, tokoh, dan setting cerita. Guru juga lebih semangat untuk bercerita karena bebas berekspresi melalui tokoh boneka yang dibawanya. Hal ini juga di dukung dan sesuai dengan pendapat yang Musfiroh (2005, p.147) "boneka menjadi alat peraga yang dianggap mendekati naturalitas bercerita". Tokoh-tokoh yang diwujudkan melalui boneka berbicara dengan gerakangerakan yang mendukung cerita dan mudah diikuti anak. Bercerita merupakan metode yang efektif dalam mengembangkan bahasa anak. Hal ini sesuai dengan pendapat Essa (2003, p.341) yang menyatakan bahwa

Stories, in their various forms, are the most popular vehicle for such activities. Stories can be told or ready by teachers, children or both together; they can be enacted by children or with flannelboard pieces, puppets, or play dough; or they can come from the rich store of children's literature or be made up out of the febric of the children's experiences. We will briefly look at some of the ways in which stories can be used and presented.

Essa menyatakan bahwa segala bentuk cerita merupakan kegiatan yang paling menarik. Cerita dapat dapat disampaikan oleh guru, anak maupun keduanya. Cerita dapat disampaikan dengan papan flanel, boneka/ wayang, play dough, atau dapat diambil dari buku-buku cerita. Anak-anak akan tertarik dengan berbagai cara dalam penyampaian cerita. Berdasarkan paparan diatas, bahwa cerita sangat membuat anak tertarik, salah satunya adalah dengan media boneka (sandiwara boneka). Apabila anak sudah tertarik dalam pembelajaran, maka guru akan lebih mudah untuk menstimulasi perkembangannya. Perkembangan bahasa khususnya keterampilan berbicara juga lebih mudah untuk terstimulasi karena sandiwara boneka mengasah imajinasi anak, apabila imajinasi anak terasah maka anak akan lebih mudah untuk mengungkapkan pendapatnya dan keterampilan berkomunikasi/ berbicaranya pun akan lebih baik. Hal tersebut juga sejalan dengan pendapat yang dikemukakan oleh Jenkins (Montolalu, 2007, p.10.12) bahwa panggung boneka dapat membantu anak untuk: (1) Mengembangkan daya kreasi dan imajinasinya; (2) Berkonsentrasi; (3) mengembangkan keterampilan berkomunikasi, (4) belajar bekerja sama; (5) mengurangi kecemasan, (6) memperoleh pengetahuan; (7) mengenalkan tentang aturan kehidupana, (8) sadar akan perilakunya.

Selain dipengaruhi oleh media dan metode permainan sandiwara boneka, keberhasilan pembelajaran bahasa dan keterampilan berbicara ini juga dipengaruhi oleh keterampilan guru dalam mengajar dan menstimulasi anak untuk berbicara dan mengungkapkan pendapatnya. Seperti di kemukakan oleh Janet Scull, Louise Paatsch, dan Bridie Raban (University of Melbourne, Deakin University, and University of Melbourne, 2013) dalam penelitiannya yang berjudul "Young Learners: Teachers' Questions and Prompts as Opportunities for Children's Language Development" menyatakan bahwa hal sangat penting untuk belajar bahasa adalah membaca buku dan melibatkan anak pada diskusi seputar teks yang dibaca. Dalam pembelajaran ini, perkembangan bahasa lisan anak prasekolah tergantung pada banyaknya peluang yang disediakan tentang keterlibatan dalam penggunaan bahasa yang disediakan oleh guru. Untuk mengeksplorasi interaksi dan keterampilan bicara anak, pertanyaan guru dalam menanggapi anak harus dilakukan dan pertanyaan terbuka memberikan kesempatan paling besar untuk anak-anak berbicara, berbagai pertanyaan yang diajukan memberikan kesempatan bagi guru prasekolah untuk memperbanyak tanggapan anak-anak, mendukung pemahaman teks, mengembangkan kosa kata dan pengetahuan, serta untuk model struktur bahasa yang lebih kompleks.

Peningkatan Keterampilan berbicara Peserta didik dapat dibahas sebagai berikut peningkatan keterampilan berbicara pada tiap siklus tidak menunjukkan suatu kestabilan. Dimana prosentase peningkatan sebe- 
lum tindakan sampai dengan siklus I mencapai 20,46\%. Dan dari siklus I sampai siklus II peningkatan mencapai $18,66 \%$. Disini diketahui bahwa sebelum tindakan sampai siklus I mengalami peningkatan yang cukup signifikan, hal ini disebabkan karena pada awal-awal pertemuan ketertarikan anak masih sangat tinggi, mereka sangat semangat dan antusias terhadap hal baru yang belum pernah ia dapatkan. Adapun untuk peningkatan dari siklus I ke siklus II, tidak mengalami peningkatan yang cukup signifikan, hal ini disebabkan oleh adanya kejenuhan yang dialami oleh anak serta terdapat beberapa aspek keterampilan berbicara yang sulit dikuasai oleh anak.

Terdapat aspek keterampilan berbicara yang mudah dkuasai oleh anak, tetapi ada juga yang sulit dikuasai oleh anak. Mengungkapkan perasaan (senang, sedih, takut) secara lisan mudah diucapkan anak, karena perasaan-perasaan tersebut sering ditanyakan oleh guru setelah selesai pembelajaran pada keseheariannya. Mengucapkan kalimat pertanyaan dengan ritme yang jelas masih terasa sulit dikuasai oleh anak. Hal ini dikarenakan mengucapkan kalimat pertanyaan merupakan tahapan keterampilan berbicara pada usia yang lebih tua yakni 5 tahun, sedangkan anak-anak kelompok A rata-rata masih berusia 4 tahun. Hal ini sejalan dengan teori tahapan keterampilan berbicara anak yang disampaikan oleh Peteda (Suhartono, 2005, p.49) menjelaskan tahapan perkembangan awal ujaran anak, yaitu penamaan, tahap telegrafis, dan tahap transformasional. Tahap Transformasional merupakan tahapan dimana pengetahuan dan penguasaan kata-kata tertentu yang dimiliki anak dapat dimanfaatkan untuk mengucapkan kalimat-kalimat yang lebih rumit. Tahapan ini dimiliki anak yang berumur lima tahun yakni sudah mulai memberanikan diri untuk bertanya, menyuruh, menyanggah, dan menginformasikan sesuatu.

Subjek penelitian ini yakni peserta didik PAUD SAYMARA kelompok A mempunyai latar belakang yang cukup baragam, baik dari segi jenis kelamin maupun dai segi usia. Terdapat 6 peserta didik peremuan dan 12 peserta didik laki-laki. Berdasarkan hasil observasi menunjukkan bahwa antara anak laki-laki dan anak perempuan secara keseluruhan keterampilan berbicanya cenderung lebih baik peserta didik laki-laki dari pada peserta didik perempuan. Berdasarkan analisis peneliti, hal ini disebabkan karena peserta didik laki-laki lebih banyak dari pada peserta didik perempuan. Dengan demikian, peserta didik laki-laki lebih percaya diri dalam pembelajaran karena merupakan kelompok mayoritas.

Adapun dari segi usia per Februari 2014, terdapat 8 anak dengan usia 5 tahun dan 10 anak dengan usia 4 tahun. Berdasarkan hasil observasi, peserta didik dengan usia 5 tahun cenderung lebih baik keterampilan berbicaranya. Hal ini sesuai dengan teori yang disampaikan oleh Penelitian oleh Jeong Hwa Lee, Jeong Eon Park (Pukyong Nasional University of Korea: 2009) yang berjudul "Differences of children's verbal interaction in peer collaboration according to age, gender, and pairing conditions". Hasil penelitian ini menunjukkan bahwa usia, gender, dan kondisi kelompok berpengaruh terhadap interaksi verbal.

Berdasarkan pembahasan tersebut, bahwa usia dan gender mempunyai pengaruh terhadap keterampilan berbicara. Pada penelitian ini, subjek penelitian bernama DN dan FR mempunyai prosentase peningkatan yang tinggi dibandingkan dengan peserta didik yang lain. Berdasarkan analisis peneliti, kedua peserta didik tersebut berusia 5 tahun dan berdasarkan pengamatan awal pada prasiklus dan informasi guru, kedua peserta didik tersebut memang lebih verbal dari peserta didik yang lain pada pembelajaran-pembelajaran sebelumnya.

Peningkatan keterampilan berbicara pada tiap-tiap indikator menunjukkan keberagaman. Pembahasan pada tiap-tiap indikator adalah sebagai berikut:

Mengucapkan bunyi artikulasi, irama/ ritme. Indikator mengucapkan bunyi artikulasi, irama/ritme dijabarkan menjadi beberapa aspek pengamatan yakni Mengucapkan bunyi vokal (a, i, u, e, o) dengan artikulasi jelas, mengucapkan bunyi konsonan bilabial (/p/,/b/,/m/,/w/), laboi-dental (/f/,dan /v/), apiko-interdental $(/ \mathrm{f} /, / \mathrm{n} /)$, apiko-alveoler $(/ \mathrm{d} /, / \mathrm{n} /)$, palatal $(/ \mathrm{c} /, / \mathrm{j} /, / \mathrm{ny} /)$ dan 
konsonan velar (:/k/,/g/,/ng/,/kh/) dengan artikulasi yang jelas, Mengucapkan kalimat pernyataan dengan irama/ritme yang jelas. Berdasarkan pengamatan, keterampilan berbicara pada peserta didik mengalami peningkatan dari prasiklus sampai siklus II. Sebelum tindakan prosentase keterampilan bebicara anak 40,5\%, meningkat di siklus 1menjadi $59,7,4 \%$ sedangkan siklus 2 mencapai $78,6 \%$.

Menyampaikan pikiran/gagasan dan perasaan secara lisan. Untuk mengetahui keterampilan berbicara anak, aspek-aspek yang diamati adalah berani mengungkapkan pikiran menggunakan 4-5 kata mengungkapkan alasan terhadap sebuah pernyataan, Mengungkapkan kalimat sebab-akibat, mengungkapkan perasaan (senang, sedih, malu, takut) secara lisan, serta mengungkapkan gagasan yang mudah dipahami orang lain. Peningkatan tiap-tiap siklus adalah sebagai berikut: prasiklus 40,8\%, siklus 1 $61,75 \%$, dan siklus 2 mencapai $83,05 \%$.

Menceritakan kembali cerita/dongeng yang pernah didengar. Untuk mengetahui keterampilan berbicara anak, aspek-aspek yang diamati adalah Menceritakan kembali cerita yang disampaikan dengan lancar, Menceritakan kembali cerita yang disampaikan dengan tepat, Menceritakan kembali isi cerita dengan bahasa anak sendiri. Peningkatan tiap-tiap siklus beragam yakni prasiklus $39,1 \%$, siklus I $61,25 \%$, dan di siklus 2 mencapai $78,66 \%$.

\section{PENUTUP}

\section{Simpulan}

Berdasarkan pembahasan pada babbab sebelumnya, maka dapat ditarik kesimpulan bahwa implementasi permainan sandiwara boneka meliputi kegiatan awal, kegiatan inti, dan kegiatan penutup. Kegiatan awal berupa apersepsi dan pengenalan tokoh, pada kegiatan inti guru menunjukkan permainan sandiwara boneka, dan kegiatan akhir peserta didik menceritakan kembali dengan permainan sandiwara boneka. Melalui implementasi permainan sandiwara boneka, keterampilan berbicara anak lebih mudah untuk terstimulasi karena sandiwara boneka mengasah imajinasi anak, apabila imajinasi anak terasah maka anak akan lebih mudah untuk mengungkapkan pendapatnya dan keterampilan berkomunikasi/berbicaranya pun akan lebih baik

Permainan sandiwara boneka dapat meningkatkan keterampilan berbicara anak usia dini. Hal ini terbukti dengan adanya peningkatan prosentase keterampilan berbicara dari sebelum tindakan sampai dengan siklus II yakni sebelum tindakan 40,13\%, siklus I mencapai $61,08 \%$, siklus II mencapai $79,74 \%$.

\section{Saran}

Berdasarkan hasil dan kesimpulan penelitian yang telah diuraikan tersebut, maka dalam usaha untuk meningkatkan keterampilan anak usia dini melalui metode permainan sandiwara diajukan sejumlah saran. Saran tersebut ditujukan kepada kepala sekolah sebagai penentu kebijakan program pembelajaran, guru kelas sebagai pelaksana pembelajaran dan peneliti berikutnya.

Kepada kepala sekolah dapat menjadi motor penggerak dalam perbaikan terhadap proses pembelajaran. Kepala sekolah sebaiknya menjaga hubungan baik dengan guru melalui kerja kolaborasi. Kepala sekolah seharusnya mendengarkan setiap masukan, kritik dan saran dari guru yang menyangkut kebijaksanaan dalam pembelajaran. Pihak sekolah harus dapat menciptakan kondisi belajar yang memadai dengan memperhatikan fasilitas dan sarana prasarana sekolah yang menunjang dalam pembelajaran khususnya pembelajaran bahasa dan berbicara seperti penyediaan alat peraga, boneka, panggung boneka, buku dan alat-alat pembelajaran yang lain. Kepala sekolah perlu dan dapat melakukan pemantauan proses pembelajaran di kelas.

Kepada Guru Kelas hendaknya menggunakan metode dan media pembelajaran berbicara yang tepat, menarik, menyenangkan dan bervariasi agar dapat membuat anak berminat dan antusias terhadap kegiatan pembelajaran. Guru kelas hendaknya melakukan pendekatan secara emosional terhadap anak, agar siswa tidak merasa minder, takut dan selalu siap dalam proses pembelajaran berbicara, sehingga lebih memotivasi dan mempermudah anak untuk 
mengingat kemudian mampu mengucapkannya dengan baik. Materi yang diberikan kepada anak hendaklah sesuai dengan konteks kehidupan anak sehingga akan lebih mempermudah anak untuk mengingat dan mengucapkan serta dapat mempraktikannya dalam kehidupan sehari-hari. Guru kelas hendaknya menyampaikan materi secara bertahap yakni dari yang mudah terlebih dahulu misalnya kata dan kalimat yang sederhana, kemudian dilanjutkan dengan kata dan kalimat yang lebih kompleks.

Kepada Peneliti Berikutnya. Peneliti berikutnya dapat melakukan penelitian yang serupa dengan penelitian ini, tetapi dalam materi dan pendekatan yang berbeda.

\section{DAFTAR PUSTAKA}

Arikunto, Suharsimi., Suhardjono, Supardi. (2007). Penelitian tindakan kelas. Jakarta: Bumi Aksara.

Bardani. (2010). Implementasi pengembangan bahasa dengan metode membacakan cerita (story reading) untuk meningkatkan kemampuan bahasa lisan pada anak didik kelompok B TK Aisyiyah II Ngadirejo. Skripsi. UMS: tidak diterbitkan

Brooks, Patricia J \& Vera Kempe. (2012). Language development. British: BPS Blackwell.

Cagri Tugrul Mart. (2012). Encouraging young learners to learn English through stories. Department of Languages, Ishik University, Erbil, Iraq: www.ccsenet.org/elt journal Vol. 5, No. 5; May 2012

Essa, Eva L. (2003). Introduction to early childhood education. Canada: Thomson

Hidayah, Rachmawati Nur. (2011). Peningkatan kecerdasan verbal linguistik anak usia dini melalui permainan punggung berantai. Skripsi. UMS: tidak diterbitkan.

Jeong Hwa Lee, Jeong Eon Park .(2009). Differences of children's verbal interaction in peer collaboration according to age, gender, and pairing conditions. Pukyong Nasional University of Korea: Asia Pacific jaurnal of research in Early Education .Vol.8, No.2, 2009, pp.105121

Mc Taggart, R (1993). Action research: $a$ short modern history. Victoria: Deakin University Press.

Musfiroh, Tadkiroatun. (2005). Bercerita untuk anak usia dini. Jakarta: Depdiknas.

Nazir, Moh. (1995). Metode penelitian. Jakarta: Ghalia Indonesia

Republik Indonesia. (2003). UndangUndang RI Nomor 20, Tahun 2003, tentang Sistem Pendidikan Nasional.

Sanjaya, Wina. (2009). Penelitian tindakan kelas. Jakarta: Kencana Premada Media Group.

Santrock, John W. (2007). Perkembangan anak. Jakarta: Erlangga.

Scull, Janet., Paatsch, Louise., \& Raban, Bridie. (2013). Young learners: teachers' questions and prompts as opportunities for children's language development. University of Melbourne, Deakin University, and University of Melbourne: Asia Pacific jaurnal of research in Early Education .Vol.7, No.1, January 2013, pp.69-91

Suhartono. (2005). Pengembangan keterampilan bicara anak usia dini. Jakarta: Diknas. 